\title{
Using Screencasts in Computer Science Classes at a Technical University
}

\author{
Irina $G$. Ustinova ${ }^{1 *}$, Olga $V$. Rozhkova $^{1}$, and Natalia $S$. Nikolaeva $^{1}$ \\ ${ }^{1}$ National Research Tomsk Polytechnic University, prosp. Lenina, 30, 634050, Tomsk, Russia
}

\begin{abstract}
The information technologies applications in various fields of human activity are developing exponentially now. The article considers possibility of using screencasting in a computer science course at a technical university. Screencast is a video that contains a record of actions performed on a computer with the author's comments. The advantages and disadvantages of this technology in the learning process are considered. It is noted that the technology of on-screen video is distinguished by information richness and strong emotional effect on the student. The application of screencasting in computer science classes at the Tomsk Polytechnic University using the mathematical package MathCad, which has the means to solve all kinds of problems associated with symbolic operations, is presented. The motivation for this study is to increase the student learning process effectiveness. Therefore, the objectives of the study are: to study the possibility of screencasting in the student learning process organization, to study the possibility of using this technology during studying a computer science course, to find out how effectively this method allows to master knowledge in the relevant discipline. The results of study using this technology and the traditional method are analyzed. It is shown that the use of screencasting allows to improve the test results in comparison with the group trained by the traditional method.
\end{abstract}

\section{Introduction}

The term "screencast" was created by John Udell in 2004 [1]. He called screencast "software videos about software recorded with speech" [2]. Thus, screencasting technology was originally intended to create online shows of software products. This technology it is used during its existence, first of all, to create educational information materials for the study of computer software packages.

However, the application area of screencasting is much wider than just the development of demonstration materials for the study of computer programs. This technology is also used in the educational process [3]. Screencasting is successfully used for creation of a wide variety of training materials related to various fields of knowledge [4-7]. This technology fundamentally changes the interaction between teacher and student. Both methods and forms of learning are changing [8]. The introduction of screencasting, that is, a video that contains a record of actions performed on a computer with the author's

* Corresponding author: igu@tpu.ru 
comments [9], allows the educational process to be taken to a qualitatively new level. The potential of screencasting is very huge: one can demonstrate his experience in using any programs or services [10], can show and explain the principles of the program or development step by step, demonstrate working with schemes using examples, etc. Without a doubt, screencasting is an effective and affordable tool of the modern educational process, which can simplify the learning process greatly [4]. The student may study the material presented in the video clip in his spare time and at a convenient pace. If student missed a lesson, then there is nothing to worry about, because with the help of a video clip he will be able to study a missed topic on his own [11]. Another important point is that the studied material presented using screencasting technology, as a rule, is ordered, planned, holistic, aimed at clarifying the topic, since its development is based on comprehensive preliminary preparation of the studied material.

\section{Aim of the research}

\subsection{MathCad as a supporting math course}

The study of computer science provides not only a certain amount of knowledge to a future engineer, economist, scientist, but also develops the ability to set, research and solve a wide variety of tasks. In other words, computer science develops the cognitive abilities of a future engineer and forms a solid foundation for the study of special disciplines. In addition, computer science develops the ability to intellectual and creative activity, perception and processing of new information the most better, affects the development of personal and professionally significant qualities of future specialists. At the Tomsk Polytechnic University, first-year students along with the computer science course take a course of higher mathematics, which begins with linear algebra and analytic geometry and continues with mathematical analysis (calculation of derivatives, construction of graphs of functions in various coordinate systems, calculation of defined, indefinite, improper, multiple, superficial, etc. limits and integrals. The traditional approach to teaching a mathematics course consists in lecturing and studying each concept discussed in the lecture in practice by solving typical examples on the studied topic. Student's education is achieved by solving tasks in the classroom, doing homeworks and individual tasks. The course is implemented through lectures and practical exercises.

In light of the reduction in classroom hours devoted to the study of mathematics, a practical course in computer science begins with the study of the MathCad system, which is considered by our teachers as a supporting course in mathematics [12].

Mathcad is a mathematically oriented universal system. In addition to the calculations, both numerical and analytical, it provides the possibility of such text design, that is difficult to accomplish using popular text editors or spreadsheets. In the Mathcad system, for example, one can prepare articles, books, dissertations, scientific reports, diploma and course projects, not only with high-quality texts, but also with an easily implemented set of the most complex mathematical formulas, an exquisite graphic representation of the calculation results and numerous examples. The use of additional libraries and packages makes it possible to use Mathcad in any field of science, technology and education [13-15].

MathCad is focused on the idea of a worksheet. Calculated expressions and equations are displayed on the worksheet in the same way as they would look on the page of a notebook, and not in the way they look in a programming language.

During laboratory works, students gain skills in solving systems of linear equations, finding determinants, finding the inverse matrix, etc. using education screencasts on the MathCad system. 


\subsection{Screencasts in an electronic resource}

The electronic resource "Fundamentals of Work in MathCad", developed on the MOODLE platform [16] (fig. 1) includes the author's audio message, 10 videos in AVI format, selfstudy tasks, and tests.
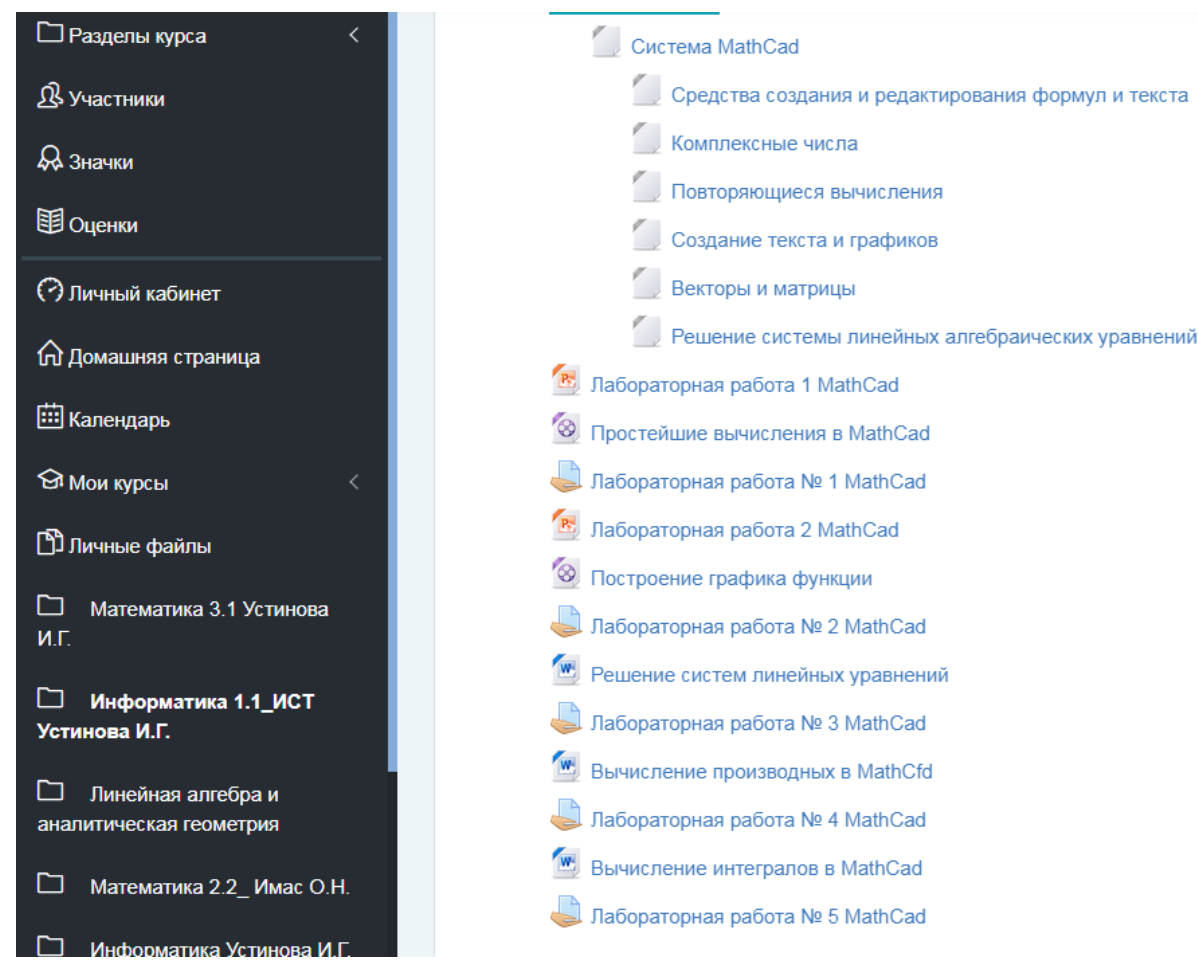

Fig. 1. Part of the electronic resource on the MOODLE platform, designed to study MathCad.

The educational videos were made using the Camtasia Studio program [17], which is the most popular video creation program. The audio message is recorded with the Sound Recorder application, which is a standard Microsoft Windows application. The program interface is made using HTML technology with Adobe Photoshop and Adobe Dreamweaver.

The proposed material is presented in the form of videos of work in MathCad with a detailed explanation of the author's actions. A screenshot to the topic "Plotting Function Graphs in MathCad" is shown in figure 2. 


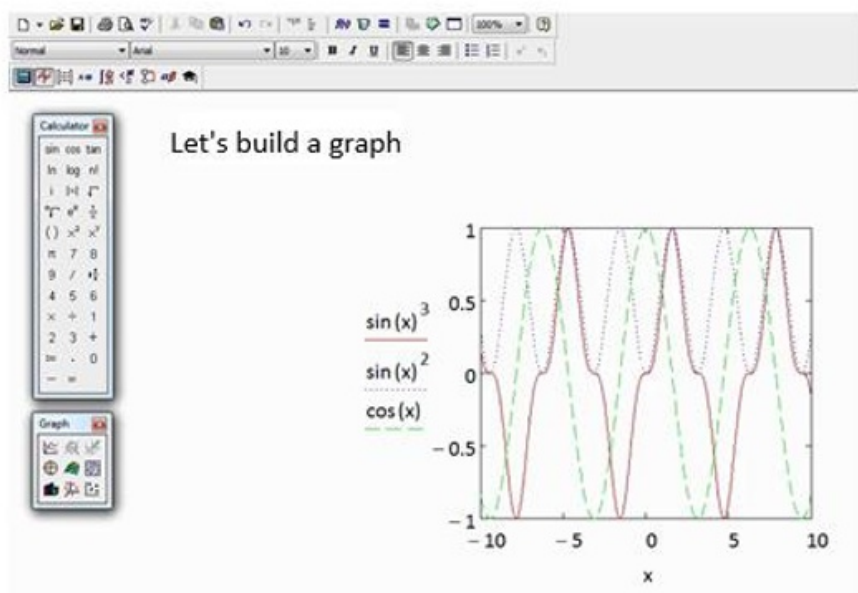

Fig. 2. Video frame of the topic "Plotting Function Graphs in MathCad".

An electronic resource is intended for an unprepared user, since the description of work in MathCad begins with an account of the very foundations of the program. The material of the education videos is well organized, contains rich graphics, which makes it comprehensively informative and vibrant and focuses the student's attention on the essence of the presented lesson, and increases interest in self-learning. The described electronic resource is actively used in the students' educational process.

Students really like this form of presentation of information (see table. 1). According to their feedback, working with an electronic resource created with screencasting technology is very convenient, as it makes it possible to study the material both visually and audibly, and at such a pace, at such a time and in place that are convenient. This brings forward the fact that students become active participants in the learning process, and also contributes to the fact that students organize their educational activities independently in accordance with the posed or arisen task.

In addition, this form of the studied material handling itself is an impetus to its use in the learning process, since it is:

1 interesting because it differs from the traditional form of education,

2 attractive because a computer is a source of information for many students.

The purpose of the study is to identify how screening technology affects the degree to which students learn the material.

\section{Results}

Two groups of students, one of which studied MathCad using videos (group 1), and the other group (group 2) studied the same system, but traditionally, i.e., with teacher's explanations and reading educational material in electronic course on the MOODLE platform, were considered. Group 1 consisted of 52 people, and the second group of 58 people. The education material for the first group was presented in the form of videos in which the use of MathCad tools was demonstrated, in accordance with the purpose of the laboratory work. At the same time, the teacher commented on how the studied fact may be used in mathematics course. The same education videos were shared for this group in an electronic resource on the MOODLE platform. After studying the topic "Getting started with the interface and basic capabilities of the MathCad mathematical package", students of 
both groups were tested. This test showed that students of group 1 mastered the principles of working in the MathCad system better. A variant of the test tasks is given in table 1 .

Table 1. Test task variant.

\begin{tabular}{|c|c|c|}
\hline $\begin{array}{c}\text { Number of } \\
\text { task }\end{array}$ & Task statement & Mark \\
\hline 1 & $\begin{array}{l}\text { Find the value of the function } \\
h(x, y . z)=\frac{x^{y+1}+e^{y-1}}{1+x|y-\operatorname{tg}(z)|}(1+|y-x|)+\frac{|y-x|^{2}}{2}-\frac{|y-x|^{3}}{3} \text { for } \\
x=2.444 ; y=0.869 \times 10^{-2} ; z=-0.13 \times 10^{3}\end{array}$ & 1 \\
\hline 2 & 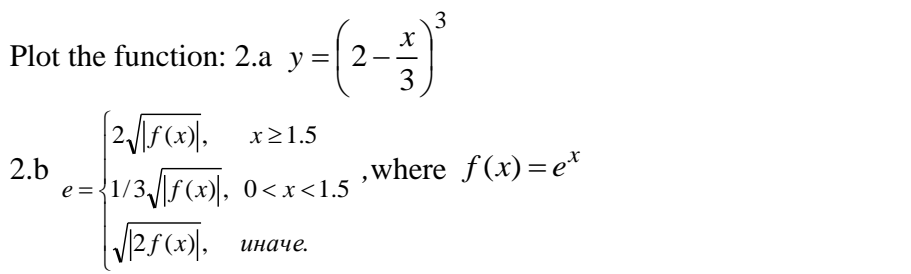 & 1 \\
\hline 3 & Solve a system of linear equations $\left\{\begin{array}{r}4 x_{1}+4 x_{2}+5 x_{3}+5 x_{4}=0 \\
2 x_{1}+3 x_{3}-x_{4}=10 \\
x_{1}+x_{2}-5 x_{3}=-10 \\
3 x_{2}+2 x_{3}=1\end{array}\right.$ & 1 \\
\hline 4 & Find the derived function $f(x)=\ln (\ln (x)-\sin (x))$ & 1 \\
\hline 5 & $\begin{array}{l}\text { Calculate: } \\
\text { 5a undefined function integral } f(x)=x^{3}-6 x^{2}+9 x+2 \text { and do a check } \\
5 \text { b definite function integral } y=\frac{1}{1+2 \sin ^{2} x} \text { on }\left[0 ; \frac{\pi}{4}\right]\end{array}$ & 1 \\
\hline
\end{tabular}

Analysis of the test results showed that students of group 1 received a higher average score for the test than students of the second group (4.54 versus 4.16), so that the percentage difference is 7.6.

To analyze the degree of students' satisfaction in working with education videos, a sociological survey of the part of students who studied MathCad with educational videos has been conducted (group 1). The results of this survey are shown in table 2. 
Table 2. Results of students' survey.

\begin{tabular}{|c|c|c|c|}
\hline $\begin{array}{c}\text { Number of } \\
\text { question }\end{array}$ & Question & Possible answers & $\begin{array}{c}\text { Answers in } \\
\%\end{array}$ \\
\hline \multirow{3}{*}{1} & \multirow{3}{*}{$\begin{array}{l}\text { Does the education video help you } \\
\text { understand the studied topic better? }\end{array}$} & Yes & 92 \\
\hline & & No & 2 \\
\hline & & Don’t know & 6 \\
\hline \multirow{3}{*}{2} & \multirow{3}{*}{$\begin{array}{c}\text { What do you think contributes to the } \\
\text { availability of education videos in } \\
\text { the electronic resource? }\end{array}$} & I understand better & 69 \\
\hline & & I remember longer & 19 \\
\hline & & $\begin{array}{l}\text { Now I'm interested in the } \\
\text { course }\end{array}$ & 12 \\
\hline \multirow[b]{2}{*}{3} & \multirow{2}{*}{$\begin{array}{l}\text { Do you like to work with education } \\
\text { videos? }\end{array}$} & Yes & 93 \\
\hline & & No & 7 \\
\hline \multirow[b]{2}{*}{4} & \multirow{2}{*}{$\begin{array}{l}\text { Does it make sense to submit } \\
\text { education videos for other sections } \\
\text { of the computer science course? }\end{array}$} & Yes & 98 \\
\hline & & No & 2 \\
\hline
\end{tabular}

Answering the first question of the survey, many students attributed the phrases: "Yes, they help a lot" or "Very useful". The reason for which a small part of the students answered negatively to this question could be that they did not need additional explanations on the topic of the lesson. They catch on very fast or were well-trained students. Answering the second question, many students $(69 \%)$ noted that screencasts help to understand the essence better. It was unexpected to us, that only $19 \%$ of respondents to question №2 answered: "I remember longer", since this group of students included not only visuals, but also those who understood the essence of the subject, that is, students who chose the first answer to the second question. The positive reaction to the shared videos in the electronic resource is apparently caused by the fact that the video lessons themselves are well thought out, ordered and are in good agreement with the studied material.

Summing up the work, we'll note the following positive aspects of the introduction of screencasting in the MathCad system study.

1. The students' interest in studying the material through videos with educational materials is increasing. Since the student works with the material at a higher level, and most importantly, he can comprehensively and at his own pace consider the studied concepts [18, 19].

2. Computer visualization allows a deeper understanding of the course essence [20].

3. Screencasting can be used as a tool to enhance the independent activities of students [4].

4. Screencasting forms the students' information culture. The teacher can create dynamic, vibrant and visual videos demonstrating tasks that are usually not addressed in the class because of their computational complexity or due to lack of time, or because such a class of tasks is not included in discipline work program.

5. Screencasting provides an opportunity for those who are sick or who have gone to camp, students to keep up with their group.

Thus, screencasting technology is one of the most effective ways of presenting educational materials. This technology is an excellent addition to the lecture course, as well 
as to the description of laboratory work, which is consistent with the study in work [21]. Screencasting can be used as an independent way to develop electronic educational materials, as well as act as an additional technology when creating large educational resources. Students' positive assessment of the instructional videos educational opportunities encourages us to use this technology in other educational resources.

\section{References}

1. J. Wagstaff, Loose Wire: A Personal Guide to Making Technology Work for You, Equinox Publishing, Jakarta (2007)

2. Choosing a Screencasting Tool, URL: http://www.indoition.com/screencasting-toolchoosing.htm, last accessed 2018/11/02.

3. S. Mohorovičić, Creation and use of screencasts in higher education, Proceedings of the 35th International Convention MIPRO, pp. 1293-1298, Opatija (2012).

4. Notess, R. Greg, Screencasting for Libraries, ALA TechSource, Chicago (2012)

5. P. Moyano, J. Del Pino, M.J. Anadon, M.T. Frejo, M.J. Díaz, M. Lobo, J. Garcia, J.M. Gariacia, M. Ruiz Fernandez, Improvement in the Academic Development of Students of Toxicology Through the Use of an Application of Screencasting, EDULEARN18 Proceedings, p. 10695, Palma, Spain (2018)

6. S. Budgett, J. Cumming, C. Miller, The role of screencasting in statistics courses, Proceedings of the 56th Session of the International Statistical Institute, Lisbon, Portugal (2007). URL: ttps://www.stat.auckland.ac.nz/ iase/publications/isi56/CPM82_Budgett.pdf, last accessed 2018/11/04.

7. T. Pinder-Grover, J.M. Millunchick, C. Bierwert, Work in progress - using screencasts to enhance student learning in a large lecture Material Science and Engineering course, 38th Annual Frontiers in Education Conference, Saratoga Springs, pp. F1A-13F1A-14, NY, USA (2008)

8. O. Rozhkova, M. Netesova, I. Ustinova, Innovative Technologies in Applied Mathematical Sciences as a Factor of Quality Improvement of Engineers' Training, ICERI2017 Proceedings, pp. 3263-3272, Seville, Spain (2017)

9. A.N. Mozolevskaya, Skrinkasting kak e`lement obrazovatel noj texnologii. of a proceedings paper, A.I. Artyunin CONFERENCE 2009, Problemy' i perspektivy razvitiya regional`nogo otraslevogo universitetskogo kompleksa IrGUPS, pp. 49-55. IrGUPS (2009)

10. M. Caukill, C. Atkins, Assessment as Learning Using Peer Reviewed Screencasting, INTED2017 Proceedings, pp. 69-73, Seville, Spain (2017)

11. A.A. Arnaiz, L.B. Escuriaza \& A.C. Gutierrez, Screencasting Experiences to Engage Blended Learning, EDULEARN17 Proceedings, pp. 3338-3345, Barcelona, Spain (2017)

12. V.F. Ochkov, E.P. Bogomolova, Teaching Mathematics with Mathematical Software, Journal of Humanistic Mathematics 5(1), pp. 265-285 (2015)

13. S.P. Tubbs, Mathcad for Electrical Engineers and Technologists, Print-on-Demand, Moscow (2009)

14. B. Maxfield, Engineering with Mathcad: Using Mathcad to Create and Organize your Engineering Calculations, Elsevier, Burlington (2006) 
15. Mathcad Version 14 (2007) PTC (Parametric Technology Corporation) Software Products URL: http://communications@ @tc.com, last accessed 2018/11/02.

16. MOODLE. URL: http://MOODLE.org, last accessed 2019/07/08.

17. Guidelines, Tips, and Suggestions for Creating Effective Screencast Tutorials Using Camtasia Software URL: http://paulinedewan.net/screencapture.pdf, last accessed 2018/11/02.

18. P. Smith, Screencasting as a Means of Enhancing the Student Learning Experience, EDULEARN17 Proceedings, pp. 6616-6621, Barcelona, Spain (2017)

19. T.B. Tunku Ahmad, F. Doheny, S. Faherty, N. Harding, How Instructor-Developed Screencasts Benefit College Students' Learning of Maths: Insights from an Irish Case Study, The Malaysian Online Journal of Educational Technology 1(4), pp. 12-25, (2013)

20. P. Hashtroodi, M. Yazdani Moghaddam, Investigating Application of Visual Thinking Strategies in Developing Audio and Visual Online Materials by Non-Native EFL Teachers: Integrating Art Assisted Language Learning (AALL) and Arts Marketing, INTED2018 Proceedings, pp. 4289-4297, Valencia, Spain (2018)

21. B. Loch, C.R. Jordan, T.W. Lowe, B.D. Mestel, Do screencasts help to revise prerequisite mathematics? An investigation of student performance and perception, International Journal of Mathematical Education in Science and Technology, 45:2, pp. 256-268 (2014) 